\title{
A Conceptual Framework to Represent the Theoretical Domain of "Innovation Capability" in Organizations
}

\author{
Ramon B. Narcizo' ${ }^{1}$ Alberto G. Canen ${ }^{2}$ \\ and lara Tammela ${ }^{3}$
}

\begin{abstract}
The term 'innovation capability' has been used recurrently in the innovation literature, but there is still considerable divergence about its meaning and implication to organizations. A consensus exists that, to innovate, organizations must possess innovation capability, and that the ownership of this feature is not a binary process, but rather an evolutionary level process. This evolutionary logic is analogous to the basic structure of organizational maturity models. However, the literature integrating innovation capability into a maturity perspective is still limited. Considering these premises, from a broad bibliographical research, this article presents a framework of reference to represent the entire theoretical domain of innovation capability. Its purpose is to classify the main types of models about this construct available in the reference literature. It is organized at increasing levels of complexity, so that each level creates the conceptual conditions for the construction of more comprehensive models. Similar to the main use cases for maturity models, there are three basic levels for the framework: descriptive; comparative; and, finally, prescriptive models of innovation capability. Considering this cumulative framework, the authors argue that, to be fully understood, innovation capability should be studied using the perspective of maturity models.
\end{abstract}

Keywords: innovation capability; conceptual framework; theoretical domain; reference model; maturity.

\footnotetext{
1 Ramon Baptista Narcizo, Assistant Professor, Department of Engineering - Science And Technology Institute, Fluminense Federal University, Rua Recife s/n, Jardim Bela Vista, Rio das Ostras - RJ, 28890-000, Brazil, e-mail: ramon. narcizo@lei.uff.br.

2 Alberto G. Canen, Full Professor, COPPE/Federal University of Rio de Janeiro, P.O. Box 68507, Rio de Janeiro, 21941-972 - RJ, Brazil, e-mail: agcanen@pep.ufrj.br.

3 lara Tammela, Associate Professor, Fluminense Federal University, Department of Engineering, Rua Recife S/N, Jardim Bela Vista, Rio das Ostras - RJ, Brazil, e-mail: iaratammela@vm.uff.br.
} 


\section{INTRODUCTION}

Innovation is widely recognized as an important mechanism for the competitiveness of companies and countries in today's globalized world (Crossan \& Apaydin, 2010; Francis \& Bessant, 2005). Included in this perspective is a recent field of knowledge related to the so-called 'innovation capability'. This organizational characteristic has gained increasing relevance as competitive environments become more challenging. Peng, Schroeder, and Shah $(2008$, p. 732$)$ described the capabilities "as high-level routines or bundles of routines"; however, there is still confusion about the definition of this term. Cusumano (2010, p. 114), for example, states that there is a problem with the concept of 'capabilities', because it "is another common yet vague term, like platforms, used in a myriad of ways". This situation has created difficulties in understanding the meaning and underlying characteristics of innovation capability.

As innovation is "the multi-stage process whereby organizations transform ideas into new or improved products, service or processes, in order to advance, compete and differentiate themselves successfully in their marketplace" (Baregheh, Rowley \& Sambrook, 2009, p. 1334), it is presumable that innovation can only occur if an organization possesses some level of innovation capability. In this sense, 'innovation capability' can be understood as the organization's potential to innovate (Saunila \& Ukko, 2012). However, Francis (2000, p. 106) explains that understanding innovation capability can be difficult, since it: "(...) is an enabling set of attributes and is detectable only when exploited; (...) possibly requires a combination of factors, both hard and soft, interacting in a complex gestalt; (and) may not be unitary and may vary between organizational levels, configurations, national or firmspecific cultures, distinctive strategies, different threat levels, technological complexity or other factors".

Lin, McDonough, Lin, and Lin (2013, p. 264) argue that it is not the capabilities themselves, but its application and use that enables the execution of activities that produce a competitive advantage. Given that capabilities are different than resources, better understanding the structure of innovation capability becomes a key issue for businesses that aspire to expand their potential to produce innovative outputs (Forsman, 2011; Lawson \& Samson, 2001; Romijn \& Albaladejo, 2002; Saunila \& Ukko, 2012). This implies the need to understand the nature of this organizational characteristic, as well as its configuration of evolution and maturation, according to the increase of organizational proficiency in relation to a set of routines and practices (Rosemann \& De Bruin, 2005). In this sense, a maturity structure can provide a useful conceptual framework to understand innovation capability, since, 
according to Röglinger, Pöppelbuß, and Becker (2012, p. 4), "maturity models typically represent theories about how an organization's capabilities evolve in a stage-by-stage manner along an anticipated, desired, or logical path".

This paper proposes a framework for the entire theoretical domain of innovation capability. This framework consists of a hierarchical structure that classifies and integrates different theoretical models for innovation capability in organizations. This is an intermediate result from a broader research project on innovation capability, whose primary objective was the construction of a universal maturity model for this construct adherent to any company, regardless of its size or sector. The framework is proposed from an extensive study of the literature about this whole domain, indicating its increasing levels of complexity and classes that comprise it. It is divided into three main levels of conceptual granularity that emulate the use perspectives for maturity models. Thus, the paper presents two main contributions. The first is that the proposed framework can be used to understand and classify how a study about innovation capability fits into a larger theoretical domain. The second, and more important, is that innovation capability, being a potential for the development of innovations in an organization, must be studied from a maturity point of view.

\section{LITERATURE REVIEW}

\section{Innovation capability}

The term 'innovation capability' is understood in varied and diffuse forms in the literature. Narcizo, Canen, and Tammela (2013) stated that there are many definitions for it, which has generated divergence both about its proper conceptualization and the contexts in which it should be employed. Lawson and Samson (2001) argued that innovation capability is a conceptual framework that aims to describe actions that can be taken to improve the success of activities and innovation efforts. This implies an essentially intangible nature, making its study challenging and complex. As a result, generally separating it from the main organizational practices is not possible, since innovation capability is exactly the potential to make these practices, with an orientation towards innovation (Saunila \& Ukko, 2013).

There is a diversity of approaches, theories and models available in the literature to represent innovation capability. Table 1 shows different definitions for this construct. However, the Resource-Based View Theory specifies important aspects to understand this organizational construct, since it assumes that innovation is based on specific routines and heuristics of organizations, not homogeneous strategies based on research and development (Som, 
Dreher \& Maloca, 2010, p. 2). Similarly, the Evolutionary Theory suggests that innovation, "far from being an isolated and defined act, is a complex process of organizational learning in all functional areas, subject to specific decisions within the system of production and dependent on various contextual factors" (Martínez-Román, Gamero \& Tamayo, 2011, p. 459).

Table 1. Definitions of innovation capability

\begin{tabular}{|c|c|}
\hline Reference & Definition \\
\hline Akman and Yilmaz (2008, p. 79) & $\begin{array}{l}\text { (...) "is defined as an important factor that } \\
\text { facilitates an innovative organizational } \\
\text { culture, characteristics of internal promoting } \\
\text { activities and capabilities of understanding } \\
\text { and responding appropriately to the external } \\
\text { environment." }\end{array}$ \\
\hline
\end{tabular}

Assink (2006, p. 219)

Essman (2009, p. 73)

Esterhuizen, Schutte, and Du Toit (2012, p. 2)

Francis (2000, p. 224)

Guan and Ma (2003, p. 740)

Lawson and Samson (2001, p. 384)

Lerro, Linzalone, and Schiuma (2009, p. 11)

Lin, Chen, and Chiu (2010, p. 113)
"The internal driving energy to generate and explore radical new ideas and concepts, to experiment with solutions for potential opportunity patterns detected in the market's white space and to develop them into marketable and effective innovations, leveraging internal and external resources and competencies"

(...) "is the organizational means with which innovative outputs may be facilitated."

(...) "is the way enterprises can generate innovative outputs."

(is) "an organizational property that underpins an ample flow of multiple, valuecreating and novel initiatives"

"is a special asset of a firm. It is tacit and non-modifiable, and it is correlated closely with interior experiences and experimental acquirement."

"the ability to continuously transform knowledge and ideas into new products, processes and systems for the benefit of the firm and its stakeholders."

"the company's ability to combine, integrate and exploit its tangible and intangible resources, to create and deliver products and services."

"the implementation or creation of technology as applied to systems, policies, programs, products, processes, devices, or services that are new to an organization." 
Olsson, Wadell, Odenrick, and Bergendahl (2010, p. 168)

Ottaviano (2004, p. 16)

Romijn and Albaladejo (2002, p. 1054)

Rangone (1999, p. 235)

Saunila and Ukko (2012, p. 358)

Santos-Vijande (2013, p. 87)

Wonglimpiyarat (2010, p. 247)

Zhao, Tong, Wong, and Zhu (2005, p. 212)

Tang, Wang, and Tang (2015, p. 139)

\section{Definition}

"Product innovation capability is defined as bundles of interrelated routines used to undertake specified product innovationrelated activities in areas such as developing new products and improving existing product quality."

"A company's innovation capability is frequently described as its ability to continuously develop innovations as a response to a changing environment."

"the ability of an organization to successfully innovate on a sustained basis."

(...) "is defined as the skills and knowledge needed to effectively absorb, master, and improve existing technologies, and to create new ones."

"that is a company' ability to develop new products and processes, and achieve superior technological and/or management performance (e.g., development cost, timeto-market, etc.)"

"The concept of innovation capability includes three elements:

(1) Innovation potential consists of factors that affect the present state of innovation capability. The factors reflect the potential that organizations have to produce innovations.

(2) Innovation processes are systems and activities that assist organizations to utilize their innovation potential and therefore enable innovations. They are the way systems and activities are carried out.

(3) The results of innovation activities are, e.g. product/service innovations, and process innovations."

(the) "ability to regularly adopt or implement more innovations in the administrative and technical domains relative to competition."

(...) "refers to the ability to make major improvements and modifications to existing technologies, and to create new technologies."

(...) "is the application of relevant knowledge to the attainment of market value" (...)

"is the capability where an enterprise utilizes its own resources to develop new products or services." 
Some relevant aspects in the propositions in Table 1 should be highlighted. The first is the idea that innovation capability is an asset or organizational property, as shown in Akman and Yilmaz (2008), Francis (2000) and Guan and $\mathrm{Ma}$ (2003). Complementary to this idea is the suggestion that innovation capability is some type of organizational ability (Lawson \& Samson, 2001; Lerro et al. 2009; Olsson et al., 2010; Ottaviano, 2004; Romijn \& Albaladejo, 2002; Rangone, 1999; Santos-Vijande, 2013; and Wonglimpiyarat, 2010). Both these perspectives are relevant and imply that innovation capability is related to the internal organizational environment in terms of experimentation, learning, adaptation, heuristics, and know-how (Forsman, 2011), reinforcing an alignment with the Resource-Based View and Evolutionary Theories (Martínez-Román et al., 2011; Som et al., 2010).

The second aspect is the idea that innovation capability is an organizational process, practice or high-level organizational routine, as observed in Essman (2009), Esterhuizen et al. (2012), O'Cass and Sok (2014), Tang et al. (2015), Saunila and Ukko (2012) and Zhao et al. (2005). At the same time, there are definitions that value the innovative outputs or successful results of these same processes or practices. In this sense, innovation capability can be understood not only as a process, but also as the innovative results from it (Lin et al., 2010; Saunila \& Ukko, 2012).

Finally, the third aspect is the idea of 'potential', as proposed by Saunila and Ukko (2012). Although present in only one definition, this term carries a central aspect for the understanding of innovation capability, as it indicates that it is present in most organizations, not only in those that innovate recurrently or systematically (Som, 2015). In other words, it is the potential for the development of innovations, and, as such, it can range from a very low level (or absent) to a very high level (or mature) (Corsi \& Neau, 2015; Essman, 2009). The definition proposed by Saunila and Ukko (2012) integrates all of the relevant aspects present in other definitions, with the inclusion of the potentiality perspective, suggesting a connection with organizational maturity models.

\section{Maturity models and innovation capability}

Assuming that in the real world there are predictable and systematic patterns for the process of organizational change and evolution, according to Röglinger et al. (2012, p. 4), "maturity models typically represent theories about how an organization's capabilities evolve in a stage-by-stage manner along an anticipated, desired, or logical path". Maturity models are useful because they can be used in three perspectives: descriptive, comparative and prescriptive. It serves a descriptive purpose when it is applied on an 'as-is' 
assessment. It is comparative when used as an internal or external benchmark mechanism, comparing performances between companies, industries, and sectors. Finally, it is prescriptive when it identifies future desirable levels of maturity, providing guidance to the implementation of the improvement actions needed to achieve them (Pöppelbuß \& Röglinger, 2011; Röglinger et al., 2012). These characteristics are particularly relevant in the context of Business Process Management.

There are several models for Business Process Management Maturity, but most are derived, to some degree, from the Capability Maturity Model (CMM) (Paulk, Curtis, Chrissis, \& Weber, 1993; Rosemann \& De Bruin, 2005). Overall, CMM is based on the proposition of five levels of maturity, defined by special requirements that are cumulative, as well as process capabilities that are expected for each level. One of the consequences of CMM was the CMM Integration (CMMI), which primarily comprises of sets of best practices that help organizations improve their processes (Röglinger et al., 2012; Stentzel, Niknam, \& Ovtcharova, 2013). CMM, and later CMMI, created a seminal conceptual framework that has served as a guideline for most organizational maturity models developed over the last two decades.

CMMI supports two paths to improve processes in organizations: continuous and stages representation. These paths are associated with two levels: capability and maturity. The path of improvement linked to capability levels, also called 'continuous representation', enables organizations to incrementally improve processes corresponding to an individual process area (or group of process areas) selected by the organization. On the other hand, the improvement path linked to maturity levels, called 'stages representation', allows organizations to improve a collection of related processes, incrementally addressing successive sets of processes. Each maturity level provides a layer in the foundation for continuous process improvement. Each level of maturity develops an important subset of the organization's processes, preparing to go to the next level, where maturity levels are measured through the achievement of objectives, both specific and general, associated with each predefined set of process areas (Chrissis et al., 2006; Paulk et al., 1993).

Particularly in the literature about innovation capability, three maturity models stand out: Bessant (2003), Corsi and Neau (2015), and Essmann (2009). Bessant (2003) proposes a maturity model based on the premise that continuous learning is a dynamic capability of the organization and can be understood as a systemic process focused on the support of incremental innovations. In terms of practices, it is structured from a maximum target, i.e. 'intense innovation capability', unfolding a set of eight skills necessary to the achievement of this target, which in turn are split, each, in three key behaviors, 
generating a total of twenty-four key behaviors. Corsi \& Neau (2015) offers the latest model available in the literature. Like CMMI, it consists of five maturity levels. Its main objective is to track the potential for innovation in each of these levels and describe the specific process that signals a greater or lesser capacity to innovate. Essmann (2009) also proposed a maturity model based on CMMI that aims to identify the organizational components of innovation capability. The model essentially encompasses three key perspectives: a conceptual framework, which supports its structure; a set of core requirements that assist in the evaluation and measurement; and a set of organizational roles, referring to the attitudes and actions of individuals in relation to innovation.

\section{RESEARCH METHODS}

As previously mentioned, the primary aim of this article is to present the first set of results of a more comprehensive research investigation on innovation capability, whose main objective is to represent this construct in a maturity structure that is adherent to companies of any size or sector. For this, it was necessary to construct a reference model based on an ontological structure that adequately represented the fundamental classes associated with this organizational characteristic. The model is based on a conceptual framework that was developed using a methodology for the construction of reference models, as proposed by Ahlemann and Gastl (2007).

The conceptual framework is a high-level perspective on the domain and it can be used to navigate it from its decomposition into smaller subunits. It aims to guarantee the fulfillment of two fundamental aspects regarding the available knowledge about the domain: (1) the certification that the modeling makes sense, and that such reference model does not yet exist; and (2) that the existing research can be incorporated into the construction of the model in question. The quality of a reference framework is usually analyzed considering its completeness, level of articulation between elements, and comprehensibility (Ahlemann \& Gastl, 2007).

For conceptual purposes, the premise adopted is that a maturity model is always a reference model, whereas the inverse is not true. This assumption is considered valid when we compare the proposals of Ahlemann and Gastl (2006) and De Bruin, Freeze, Kaulkarni, and Rosemann (2005) for the construction of reference and maturity models, respectively. The adoption of this premise is justified, because it makes possible the construction of a conceptual framework on the domain of innovation capability, which 
incorporates a maturity structure without the risk of conceptual overlaps or contradictions.

The research began by analyzing 1,672 documents available in the Scopus database containing the exact term 'innovation capability' in its titles, abstracts or keywords. From these documents, citation information, bibliographical information, abstracts, keywords and references were captured and exported. The data were then analyzed using VOSViewer and CitNetExplorer software. VOSViewer was used to construct and visualize bibliometric networks based on co-citations, bibliographic coupling or coauthorship relations, while CitNetExplorer was used to view and analyze citation networks in this domain over the last twenty decades. For a better understanding of the operation of these tools, we suggest consulting Van Eck and Waltman (2014).

From the analysis performed by the software, approximately 300 key documents were selected for a more comprehensive analysis. A detailed study of these documents revealed that it was possible to identify three main types of models that structure the theoretical domain of innovation capability. These models were placed in an ontological hierarchy, emulating, in increasing order of complexity, the use principles for maturity models. For each level of complexity in the framework, two sub-classes of models were identified. The way all entities of the framework relate to each other and contribute to the construction of the new levels of greater conceptual complexity on the domain was then explained. Finally, it was possible to construct a complete conceptual framework for the theoretical domain of innovation capability, which is illustrated in Figure 2.

\section{ANALYSIS}

Starting from the scanning and analysis of the literature on the theoretical domain of innovation capability, it was possible to identify a fundamental framework of constructs that comprise it. The domain is fundamentally structured by a typology of models analogous to the predicted use cases for maturity models. There are three main classes: (1) descriptive, (2) comparative, and (3) prescriptive models. These models represent a structure of increasing complexity, where each one has two subclasses of models. For the descriptive models, there are the subclasses of 'definitions' and 'organizational dimensions and (or) organizational results'. For the comparative models, there are the subclasses of 'conceptual diagrams' and 'assessment instruments'. Finally, for the prescriptive models, there are 'reference (or maturity) models' and 'standards'. Subclasses are cumulative 
in complexity, so each level of the framework depends on a set of subclasses of the previous one. Thus, prescriptive models (Level 3) are enabled from the subclasses of the comparative models (Level 2), which, in turn, are enabled from the subclasses of the descriptive models (Level 1 ). Figure 2 illustrates this conceptual framework.

Descriptive models are characterized by employing one or more entities that, per se, are insufficient to adequately represent all characteristics of innovation capability in an organization. These models are generally used to describe or define innovation capability without a comparative or prescriptive purpose, although this is not a universal rule. In short, these models are focused on 'what', without paying much attention to 'how'. Consequently, models in this class may differ significantly from each other in terms of scope and completeness. Therefore, this is the most heterogeneous and highly granular class of models, in which conceptual overlapping or even theoretical contradictions can occur. The main subclasses of the descriptive models are:

Definitions: These models fundamentally aim to characterize, define or conceptualize innovation capability in organizations. A definition is the simplest model available in the literature, and can be understood as the 'smallest possible entity' in this domain. Usually, all other subclasses of models are deployed from a definition for innovation capability. Examples of definitions for innovation capability can be found in: Akman and Yilmaz (2008), Assink (2006), Guan and Ma (2003), Hu (2008), Rangone (1999), Wonglimpiyarat (2010) and Zhao et al. (2005).

Organizational dimensions: These models describe sets of organizational dimensions that directly influence an organization's innovation capability. In some cases, authors also present sets of management processes related to these dimensions. Thus, these models are generally targeted at the internal organizational environment. Generally, organizational dimensions are proposed from a supporting definition. Some of the most common organizational dimensions are: leadership, strategy, organizational structure, culture, processes, and human resources. Examples of organizational dimensions related to innovation capability can be found in Branzei and Vertinsky (2006), Laforet and Tann (2006), Martínez-Román et al. (2011), Narcizo et al. (2013) and Perdomo-Ortiz, González-Benito, and Galende (2006).

Organizational results: These models are usually focused on the organization's innovation performance, with a primary perspective on the market, customers, and competitors. In this way, these models are more oriented to the impact that innovations produce in the external environment, in terms of the competitiveness, efficiency and performance. Generally, organizational results are also proposed from a supporting definition for 
innovation capability. Examples of organizational results related to innovation capability can be found in Hervas-Oliver, Sempere-Ripoll, and Arribas (2015), Laforet (2011), Simpson, Siguaw, and Enz (2006) and Saunila, Pekkola, and Ukko (2014).

Comparative models aim to represent the dynamics of innovation capability in an organization, usually with the intention of evaluating, measuring or comparing the dynamics between organizations. Comparative models are divided into two subclasses. The first concerns conceptual diagrams. These models are often based on a definition of innovation capability and dimensions and (or) organizational results, making it possible to construct assessment instruments. The latter, in turn, enables diagnostics, benchmarks and comparative studies of innovation capability across organizations. The main subclasses identified for comparative models are:

Conceptual diagrams: These models aim to build a diagram that supposedly represents the dynamics of innovation capability, commonly representing the organization as a system, consisting of internal and external entities, inter-related, and operating from inputs, transformations and outputs. In general, these models employ a definition, organizational dimensions and (or) organizational results to construct the diagram. Examples of conceptual diagrams for innovation capability can be found in Lawson and Samson (2001), Smith, Busi, Ball, and Van Der Meer (2008), Crossan and Apaydin (2010) and White and Bruton (2011).

Assessment instruments: These models aim to build assessment instruments to measure innovation capability in organizations. These models can also be used as comparative tools, giving them the ability to produce a diagnosis of this feature among organizations. Generally, assessment instruments are constructed from a supporting conceptual diagram. Examples of innovation capability assessment instruments can be found in Ottaviano (2004), Aiman-Smith (2005), Martínez-Román et al. (2011), Saunila and Ukko (2012).

Prescriptive models aim to represent innovation capability in its entirety, usually through the use of reference or maturity structures. These models usually have, in addition to a supporting conceptual framework and definition, an assessment tool, as well as proposals of good practices resulting from the assessment. These models tend to have greater conceptual density, usually derived from extensive applied studies in several organizations. However, they are rarer and appear in smaller numbers in the literature. The main subclasses include:

Reference models: These models aim to develop innovation capability in organizations through a frame of reference. With the exception of Francis (2000), all models in this subclass are based on a maturity structure, with 
defined evolutionary levels and good practices associated with each level. The most relevant models in this subclass are in Bessant (2003), Corsi and Neau (2015), Essmann (2009) and Francis (2000).

Standards: These are the most recent and complex class of models in the entire domain. Models in this subclass consist of propositions of universal patterns related to innovation capability and its management, presuming the existence of universal standards that, if respected, would turn innovation into another organizational process, as happened with the other fields of knowledge in the past. The most relevant models in this subclass are still under development. They include the European Committee for Standardization Technical Committee CEN/TC 389 - Innovation Management (CEN, 2016) and the International Organization for Standardization Technical Committee ISO/ TC 279 - Innovation management (ISO, 2016).

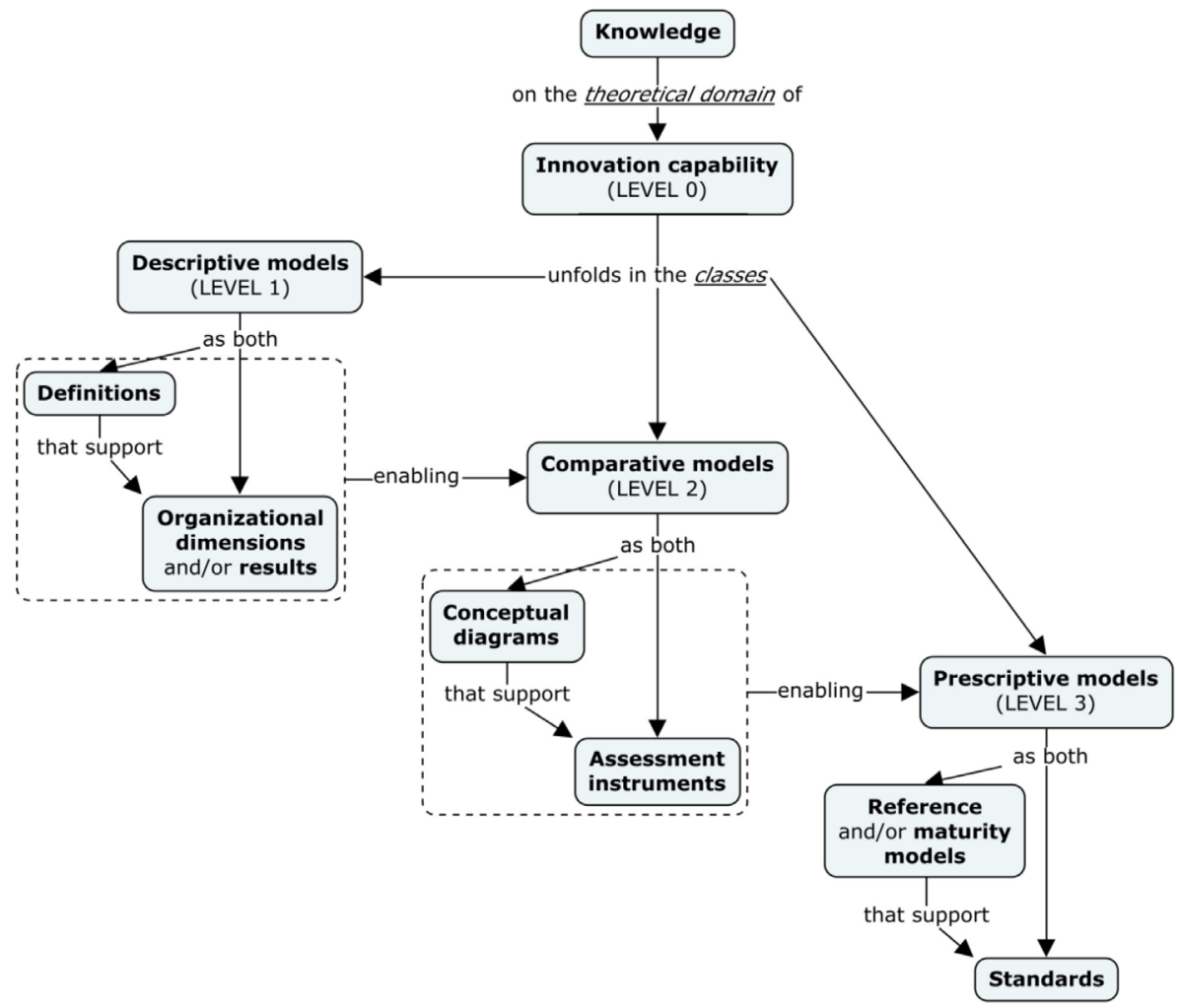

Figure 2. Proposed framework for the theoretical domain of innovation capability 


\section{DISCUSSION}

The main contribution of this article is the proposal of a framework, in the form of a hierarchical structure that classifies and integrates different theoretical models for innovation capability, presented in Figure 2. This structure is an 'embryonic' model of an ontological representation for this theoretical domain, denoting a seminal proposition for a potential new field of knowledge still underexplored in the literature. This representation can also be useful as an instrument of compatibility between models, from its frames in the classes defined by the hierarchy. Therefore, distinct models can be combined and integrated into more complex and comprehensive theoretical models, from their classification in the framework. Therefore, the framework has significant potential for theoretical and practical developments and can be useful, for example, as an artifact to support the construction of information systems or modeling organizational processes related to organizational innovation capability.

The framework offers an expansion of the theory about fundamental characteristics of "innovation capability" as a construct. It has particular adherence to the perspective proposed by Saunila \& Ukko (2014) regarding the idea that innovation capability represents a potential for innovation. At the same time, it is also aligned with the propositions of Corsi and Neau (2015) and Essmann (2009), stating that, based on the structure of available literature on this construct, the theoretical knowledge about innovation capability emulates the structure of a maturity model.

However, although the proposed framework represented by Figure 2 has a defined hierarchical structure, it should not be considered entirely rigid. Therefore, it is prudent to analyze it with some flexibility in mind. There are some issues that still merit further study. For example, in relation to the first level of the framework, although there is no doubt that descriptive models constitute the most elementary level of the domain there are still concerns about its constituent subclasses. In some cases, it was observed that conceptual diagrams could be qualified as descriptive, rather than comparative, models. Similarly, it was observed that, in some cases, organizational dimensions and results could be classified as comparative, rather than descriptive, models. The configuration presented in Figure 2 was chosen by adopting the premise that dimensions and organizational results help in the description of the fundamental structure of innovation capability, while conceptual diagrams help in the construction of instruments for its evaluation. However, as explained, this configuration should not be understood as a universal rule for all existing theoretical models. 
There are also opportunities for discussion about the hierarchical relationship between comparative and prescriptive models. Generally, in the literature on maturity models, prescriptive uses of these models tend to occur before its use for comparative purposes. That is, the comparative use tends to be a natural unfolding or an evolution from the prescriptive use. For the case of the theoretical domain of innovation capability, the inverse is suggested. The discussion of prescriptive models for innovation capability, especially in the form of rules or universal standards, is still in its early stages of development, e.g. the Innovation Management guidelines, by the ISO Technical Committee 279. And yet there is no consistent indication that these standards will be accepted, used and disseminated by stakeholders and related communities. On the other hand, the evaluation and comparison models of innovation capability have been developed for a long time. Furthermore, most of the identified maturity models were initially developed from studies about evaluating the innovation capability of organizations, to then construct maturity levels, and not the inverse. Thus, particularly in the literature on innovation capability, prescriptive models tend to be dependent on comparative models.

The standards also merit particular reflection. These types of models are characterized by being the most recent and immature class of the domain, since there is no innovation standard that is currently widely adopted, accepted or recognized, either by the Academy or by the market. Thus, although designed to assume a normative role, they are not yet widely recognized as such by their potential users. This is because they are derived, for the most part, from propositions designed with the intention of constructing frames of reference, varying in terms of customization and flexibility, to guide - and eventually certify - innovation processes in organizations. These models must be understood differently from all other prescriptive models found in the literature, since their conceptual support and construction processes tend to be closed (not explicit) and can vary significantly in terms of conceptual adherence, indication of best practices, universality, usability, intelligibility, flexibility and completeness, particularly in the case of small or low-tech companies. However, as occurred with other normative propositions, one or more of these prescriptive models can evolve in a similar trajectory, eventually becoming accepted by a community of users and becoming a widely recognized and adopted standard. This implies that systems, methods and tools for the certification of innovation capability or innovation management processes can become a routine situation in the near future.

Considering these aspects about the framework, two main implications arise. The first implication is that the conceptual framework proposed in 
Figure 2 can provide a structure for the understanding of how a study about innovation capability fits into a larger theoretical domain. It also helps to explain the different degrees of complexity that these models can assume. In a synthesized way, the framework determines how most studies, even with different scopes and objectives can be complementary to the construction of this field of knowledge. It also proposes that the theoretical domain about innovation capability is structured in an analogous way to the cases of the use of maturity models, suggesting that this construct itself can also be represented using a maturity structure.

As a consequence, a second implication is suggested: that innovation capability, being the innovation potential, process, and results (Saunila \& Ukko (2014) must be analyzed from a maturity point of view. This is fundamentally due to the fact that a 'potentiality' represents a plausible, but not necessarily concretized, situation. In other words, it expresses a likely possibility to exist or happen. This view is adhered to the logic of maturity, since the susceptibility of an organizational performance level will vary (increase or decrease) due to the organization's degree of proficiency in a bundle of routines (Chrissis et al., 2006). This is the same premise underlying a maturity model because, as it is structured in levels, maturity will increase as the organization complies with certain requirements and achieves a degree of evolution in its business processes (De Bruin et al., 2005). Bessant (2003, p. 56) summed up this discussion by stating that dealing with innovation is "not dealing with a binary state, a simple 'on/off' switch", that is, there is a whole spectrum of possibilities for innovation capability, which grow from a very low or nonexistent level, to a very high or mature level.

\section{CONCLUSIONS}

This article proposes that the entire theoretical domain on the innovation capability of organizations can be condensed into a framework. This framework is proposed and deployed in three main classes, which emulate the principles of use for maturity models. However, it is relevant to point out that this proposal is an intermediate result of a broader research investigation that is still under development. Despite this, some conclusions are already possible. Firstly, the authors consider that the framework can be an important tool for the classification of theoretical models, both existing and future, regarding innovation capability. Thus, it can be used as a classification and ordering mechanism of available knowledge, resembling an ontology for the domain. It may also be useful to help understand how different models can be related in a complementary way, without there being theoretical contradictions in 
its combined uses. Finally, it can be used for the construction of maturity models about innovation capability, as the framework describes increasing and cumulative levels of conceptual complexity.

The authors believe that there are still opportunities for improvements and adjustments to the framework, but also understand that this is already an important step in better understanding the entire theoretical domain about innovation capability. As proposals to expand this research, two developments are suggested. The first is a more comprehensive empirical validation of the framework, in order to guarantee that it is a faithful representation of reality. This validation process could be carried out through questionnaires and interviews with recognized experts in this field of knowledge, assuring the construction of a reference framework based on the empirical evidence. The second is the development of a method oriented to the construction of a maturity model for innovation capability in organizations. This method could use the relationship between subclasses proposed in this framework to build a more integrated and comprehensive theory about this construct. Thus, instead of developing new models, researchers can use this framework to take advantage of models already available in the literature, gaining time, quality and efficiency in the study and modeling the innovation capability in organizations.

\section{References}

Ahlemann, F., \& Gastl, H. (2007). Process model for an empirically grounded reference model construction. In P. Fettke \& P. Loos (Eds.), Reference modeling for business systems analysis (pp. 77-97). Hershey, PA: Idea Group Pub.

Akman, G. Sen, \& Yilmaz, C. (2008). Innovative capability, innovation strategy and market orientation: An empirical analysis in Turkish software industry. International Journal of Innovation Management, 12(1), 69-111.

Assink, M. (2006). Inhibitors of disruptive innovation capability: A conceptual model. European Journal of Innovation Management, 9(2), 215-233.

Baregheh, A., Rowley, J., \& Sambrook, S. (2009). Towards a multidisciplinary definition of innovation. Management Decision, 47(8), 1323-1339.

Bessant, J. R. (2003). High-involvement Innovation: Building and Sustaining Competitive Advantage through Continuous Change. Hoboken, NJ: J. Wiley.

Chrissis, M. B., Konrad, M., \& Shrum, S. (2006). CMMI ${ }^{\circledR}$ Second Edition: Guidelines for Process Integration and Product Improvement. SEI Series in Software Engineering.

Corsi, P., \& Neau, E. (2015). Innovation Capability Maturity Model. Hoboken, NJ: ISTE Ltd/John Wiley and Sons Inc. 
Cusumano, M. A. (2010). Staying Power: Six Enduring Principles for Managing Strategy and Innovation in an Uncertain World (Lessons from Microsoft, Apple, Intel, Google, Toyota and More). Oxford: OUP.

De Bruin, T., Freeze, R., Kaulkarni, U., \& Rosemann, M. (2005). Understanding the main phases of developing a maturity assessment model. Australasian Conference on Information Systems (ACIS) (pp. 8-19). Retrieved from http://eprints.qut.edu.au/25152/

Essmann, H. E. (2009). Toward innovation capability maturity. Doctoral dissertation, Stellenbosch: University of Stellenbosch.

Esterhuizen, D., Schutte, C., \& Du Toit, A. (2012). A knowledge management framework to grow innovation capability maturity. SA Journal of Information Management, 14(1), 1-10.

Forsman, H. (2011). Innovation capacity and innovation development in small enterprises. A comparison between the manufacturing and service sectors. Research Policy, 40(5), 739-750.

Francis, D. L. (2000). Assessing and improving innovation capability in organizations. Doctoral dissertation, University of Brighton.

Francis, D., \& Bessant, J. (2005). Targeting innovation and implications for capability development. Technovation, 25(3), 171-183.

Guan, J., \& Ma, N. (2003). Innovative capability and export performance of Chinese firms. Technovation, 23(9), 737-747.

Lawson, B., \& Samson, D. (2001). Developing innovation capability in organisations: A dynamic capabilities approach. International Journal of Innovation Management, 5(3), 377-400.

Lerro, A., Linzalone, R., \& Schiuma, G. (2009). Modelling organisational innovation capability: A knowledge-based approach. Proceedings of the 4th IFKAD.

Lin, H. E., McDonough, E. F., Lin, S. J., \& Lin, C. Y. Y. (2013). Managing the exploitation/exploration paradox: The role of a learning capability and innovation ambidexterity. Journal of Product Innovation Management, 30(2), 262-278.

Lin, R.-J., Chen, R.-H., \& Kuan-Shun Chiu, K. (2010). Customer relationship management and innovation capability: An empirical study. Industrial Management \& Data Systems, 110(1), 111-133.

Martínez-Román, J. a., Gamero, J., \& Tamayo, J. a. (2011). Analysis of innovation in SMEs using an innovative capability-based non-linear model: A study in the province of Seville (Spain). Technovation, 31(9), 459-475.

Narcizo, R. B., Canen, A. G., \& Tammela, I. (2013). SME's innovation capability as a resource to meet future logistical demands of Brazilian oil industry. Annals of the Faculty of Engineering Hunedoara, 11(1), 157. Retrieved from http://annals.fih.upt.ro/pdf-full/2013/ ANNALS-2013-1-21.pdf

O'Cass, A., \& Sok, P. (2014). The role of intellectual resources, product innovation capability, reputational resources and marketing capability 
combinations in firm growth. International Small Business Journal, 32(8), 996-1018.

Olsson, A., Wadell, C., Odenrick, P., \& Bergendahl, M. N. (2010). An action learning method for increased innovation capability in organisations. Action Learning: Research and Practice, 7(2), 167-179.

Ottaviano, M. E. (2004). Assessing and improving the enablers of innovation: The development of an Innovation Capability Assessment instrument. Australia: Australian Graduate School of Entrepreneurship at Swinburne University of Technology.

Paulk, M., Curtis, B., Chrissis, M. B., \& Weber, C. V. (2002). Capability maturity model for software. In Encyclopedia of Software Engineering (vol. 10, pp. 18-27). Hoboken, NJ, USA: John Wiley \& Sons, Inc.

Peng, D. X., Schroeder, R. G., \& Shah, R. (2008). Linking routines to operations capabilities: A new perspective. Journal of Operations Management, 26(6), 730-748.

Pöppelbuß, J., \& Röglinger, M. (2011). What makes a useful maturity model? A framework of general design principles for maturity models and its demonstration in business process management. Ecis, Paper 28. Retrieved from http://aisel.aisnet.org/ecis2011/28/

Rangone, A. (1999). A resource-based approach to strategy analysis in smallmedium sized enterprises. Small Business Economics, 12(3), 233-248.

Röglinger, M., Pöppelbuß, J., \& Becker, J. (2012). Maturity models in business process Management. Business Process Management Journal, 18(2), 328-346.

Romijn, H., \& Albaladejo, M. (2002). Determinants of innovation capability in small electronics and software firms in southeast England. Research Policy, 31(7), 1053-1067.

Rosemann, M., \& De Bruin, T. (2005). Application of a holistic model for determining BPM maturity. BPTrends, (February), 1-21.

Santos-Vijande, M. L., González-Mieres, C., \& López-Sánchez, J. Á. (2013). An assessment of innovativeness in KIBS: Implications on KIBS' co-creation culture, innovation capability, and performance. Journal of Business \& Industrial Marketing, 28(2), 86-102.

Saunila, M., \& Ukko, J. (2012). A conceptual framework for the measurement of innovation capability and its effects. Baltic Journal of Management, 7(4), 355-375. Saunila, M., \& Ukko, J. (2013). Facilitating innovation capability through performance measurement: A study of Finnish SMEs. Management Research Review, 36(10), 991-1010.

Saunila, M., Pekkola, S., \& Ukko, J. (2014). The relationship between innovation capability and performance. International Journal of Productivity and Performance Management, 63(2), 234-249.

Smith, M., Busi, M., Ball, P., \& Van Der Meer, R. (2008). Factors influencing an organisation's ability to manage innovation: a structured literature review and conceptual model. International Journal of Innovation Management, 12(04), 655-676. 
Som, O., Dreher, C., \& Maloca, S. (2010). Innovation Patterns of non-R\&Dperforming firms in the German manufacturing industry. In 13th Conference of the International Schumpeter Society (vol. 1). Aalborg University, Denmark.

Stentzel, T., Niknam, M., \& Ovtcharova, J. (2014). Comparison framework for PLM maturity models. In IFIP International Conference on Product Lifecycle Management (pp. 355-364). Germany: Springer Berlin Heidelberg.

Tang, T.-W., Wang, M. C.-H., \& Tang, Y.-Y. (2015). Developing service innovation capability in the hotel industry. Service Business, 9(1), 97-113.

White, M. A., \& Bruton, G. D. (2010). The Management of Technology and Innovation: A Strategic Approach. London: Cengage Learning.

Wonglimpiyarat, J. (2010). Innovation index and the innovative capacity of nations. Futures, 42(3), 247-253.

Zhao, H., Tong, X., Wong, P. K., \& Zhu, J. (2005). Types of technology sourcing and innovative capability: An exploratory study of Singapore manufacturing firms. Journal of High Technology Management Research, 16(2), 209-224.

\begin{abstract}
Polish)
Termin „zdolność do innowacji” był wielokrotnie stosowany w literaturze z zakresu innowacyjności, ale nadal istnieje znaczna rozbieżność co do jego znaczenia i implikacji dla organizacji. Zgoda istnieje co do tego, że być innowacyjnym organizacje musiały posiadać zdolność innowacyjnq, a własność tej funkcji nie jest procesem binarnym, a raczej procesem ewolucyjnym. Logika ewolucyjna jest analogiczna do podstawowej struktury modeli dojrzałości organizacyjnej. Jednakże literatura włączajq̨ca zdolności innowacyjne do perspektywy dojrzałości jest wciqż ograniczona. Biorqc pod uwagę te przesłanki, z szerokiego badania bibliograficznego, niniejszy artykuł przedstawia ramy odniesienia do reprezentowania catej teoretycznej dziedziny zdolności innowacyjnych. Jego celem jest klasyfikacja głównych typów modeli dotyczqcych tego konstruktu dostępnych $w$ literaturze referencyjnej. Jest on zorganizowany na coraz większym poziomie złożoności, dzięki czemu każdy poziom tworzy konceptualne warunki budowy bardziej wszechstronnych modeli. Podobnie jak w przypadku zastosowań głównych dla modeli dojrzałości, istnieja trzy podstawowe poziomy: opisowy, porównawczy oraz normatywny model zdolności innowacyjnych. Biorqc pod uwagę te skumulowane ramy, autorzy twierdzq, że należy w pełni zrozumieć zdolność innowacyjnq do badania, biorq̨ pod uwagę modele dojrzałości.
\end{abstract}

Słowa kluczowe: zdolność do innowacji; ramy koncepcyjne; dziedzina teoretyczna; model referencyjny; dojrzałość. 


\section{Biographical notes}

Ramon Baptista Narcizo is an Assistant Professor in the Engineering Department, Science and Technology Institute, at Fluminense Federal University (Rio de Janeiro State, Brazil). He specializes in innovation and technology management. His research focuses on innovation capability in small and medium-sized low-tech enterprises. Contact: ramon.narcizo@lei. uff.br.

Alberto G. Canen is a Full Professor at COPPE, Federal University of Rio de Janeiro (Rio de Janeiro, Brazil). He has extensive experience in organizations and also as a consultant. His main research is focused on operational research, logistics and supply chain management with multicultural aspects. Contact: agcanen@pep.ufrj.br.

Iara Tammela is an Associate Professor in the Engineering Department, Science and Technology Institute, Fluminense Federal University (Rio de Janeiro State, Brazil). She specializes in Production Engineering, with an emphasis on Operational Research. Her research is focused on logistics, competitive advantages and time-based competition. Contact: iaratammela@vm.uff.br. 